Article

\title{
Physical Strength Perception of Older Caregivers in Rural Areas
}

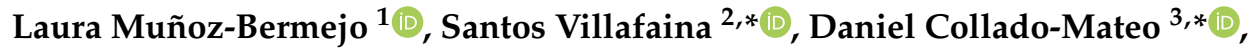 \\ Salvador Postigo-Mota ${ }^{4}$ and José Carmelo Adsuar ${ }^{2}$ (I) \\ 1 University Center of Mérida, University of Extremadura, 06800 Mérida, Spain; lauramunoz@unex.es \\ 2 Faculty of Sport Science, University of Extremadura, 10003 Cáceres, Spain; jadssal@unex.es \\ 3 Centre for Sport Studies, Rey Juan Carlos University, 28943 Fuenlabrada, Madrid, Spain \\ 4 Faculty of Medicine, University of Extremadura, 06006 Badajoz, Spain; spostigo@unex.es \\ * Correspondence: svillafaina@unex.es (S.V.); danicolladom@gmail.com (D.C.-M.)
}

Received: 18 June 2019; Accepted: 14 October 2019; Published: 16 October 2019

\begin{abstract}
Background and objective: In an aging population, it is increasingly common for older adults to take care of other older adults. Caregiving tasks may be conditioned by the aging process. This study aims to analyze the perceived physical strength of older caregivers and its impact on the functional capacity to engage in caregiving activities. Methods: A discretionary sampling of caregivers $(N=107)$, $\geq 65$ years old, in the rural health area of Badajoz (Spain) participated in this cross-sectional study. Measurements included questions about the caregiver's role (experience, years, hours, difficulties, demands) and their perceived physical strength, ability to perform activities of daily living (ADL), need for help or difficulty for caring. Results: Older caregivers from rural areas perceived a lack of physical strength (71\%). These caregivers need more help, have more difficulties, and show less ability to perform ADL. Furthermore, around $80 \%$ of the people who had a lack of strength were caring for people with severe or total dependence. There is a direct correlation between the perceived lack of physical strength and the ability to perform basic $(r=0.382, p<0.01)$ and instrumental $(r=0.370$, $p<0.01)$ activities. Conclusions: Therefore, the perception of strength and the characteristics of the cared for person may be crucial variables to successfully conduct caregiving tasks.
\end{abstract}

Keywords: caregivers; aging; muscle strength; older adults; independence

\section{Introduction}

The increase in the population's life expectancy has increased the demand for older adult care in western industrialized countries [1]. A new challenge has been presented to health systems that coincides with profound changes in the social, family, and caregiver structure [2]. Usually, the care demands fall upon informal caregivers, i.e., the family, which is the primary health care provider [3]. In this regard, these chores are commonly assumed by kinships' older adults, such as the wife or husband, siblings, and even children exceeding the chronological barrier of 60 years [4]. Thus, informal care is mostly assumed by older parents (32\%) and spouses (36\%) [5].

According to the Informal Support Survey for older adults in Spain, more than $30 \%$ of older caregivers are over the age of 65 [6]. The caregiving role in older people can lead to poor health outcomes $[7,8]$ with familial, social, economic, and spiritual consequences [9]. Moreover, older caregivers are more affected by physical burden [10], demand more health services [11], and receive less social support [12]. Furthermore, the development or worsening of health problems is associated with increased susceptibility to these burdens [13]. For these reasons, older caregivers report greater dependence on instrumental activities of daily living (IADL) [14] and greater morbidity associated with physical frailty [15], which implies a decrease in the quality of life related to health [16] and satisfaction with life [17]. 
The decrease in age-related muscle mass is an important health problem and has a negative influence on the ability to perform daily life tasks, which leads to a reduced quality of life [18]. Caregivers are also aware of their weakened strength and health problems caused by aging, which diminishe their ability to provide care, increase their efforts to assist, and make them feel more tired [19]. Therefore, older caregivers present a diminished capacity and dedication to develop caregiving tasks $[4,20]$.

There are many sources of care for people with long-term chronic illnesses, and there are specific directives for their caregivers. To obtain excellence in the care of people suffering from chronic diseases, the focus of care should be on the caregiver [2]. It is important that resources and strategies are offered so that the caregiver can manage daily challenges in full support of physical safety and activity performance [21-23].

Therefore, the main aim of the present study was to evaluate the perceived lack of strength among older caregivers in rural areas. Moreover, we aimed to identify gender differences and the influence of the perceived lack of strength in care-related variables, such as difficulties, need for help, or characteristics of the care recipient.

\section{Materials and Methods}

\subsection{Participants}

A total of 107 participants ( $N=107$; with a median \pm IQR of $78 \pm 8$ years) were included in this cross-sectional study. Regarding gender, the participants included 64 women (59.8\%) and 43 men $(40.2 \%)$. All participants gave written consent to participate in the study. Procedures were approved by the University Research Ethics Committee (approval number: 212/2019 from 8 October 2019).

Inclusion criteria included:

(1) Living in a rural town (fewer than 10,000 inhabitants);

(2) Being older than, or equal to, 65 years old;

(3) Being the primary caregiver of a dependent adult older than or equal to 65 years old. We considered primary caregivers those who assume responsibility for nursing and provide the highest amount of care;

(4) Being able to give written informed consent.

\subsection{Procedure}

Data were collected from each caregiver through an individual interview that was performed in each caregiver's home. The interview was arranged with the support of the Social Work Service of the Health Centers.

The Caregivers Questionnaire, included in the Disability, Personal Autonomy, and Dependency Situations Survey (AGE 2008) [24] was used as a reference. In this regard, the caregivers' perception of physical strength was assessed through item number 15 of the Caregivers Questionnaire of the National Statistics Institute. This dichotomous item referred to the "perception of special difficulty due to the lack of physical strength".

Moreover, the Barthel Index [25], consisting of ten activities graded according to the patient's level of dependence, was used to assess the ability to perform the primary activities of daily living (ADL). These activities include: eating (score 5 or 10); bathing/washing (score 0 or 5); dressing (score 5 or 10) grooming (score 0 or 5); deposition (score 5 or 10); urinating (score 5 or 10); toileting (score 5 or 10); transfers chair/bed (score 5, 10, or 15); mobility (score 5, 10, or 15); and going up and down stairs (score 5 or 10). The sum of each ADL score is the Barthel Index total score, which can range from 0 to 100 . The higher the score, the more independent the patient. The Barthel Index presents inter-observer reliability between 0.47 and 1.00 , and intra-observer reliability between 0.84 and $0.97[26,27]$. The internal consistency corresponds to a Cronbach's alpha of $0.86-0.92$ [28] in the original version.

The Lawton and Brody index [29] was used to determine the capacity to perform IADL. This index includes eight activities (ability to use the telephone, shopping, meal preparation, housekeeping, 
laundry, use of transport, responsibility for medication, and handling financial matters). Each area scores a maximum of 1 and a minimum of 0 points. Thus, maximum dependence would be considered 0 points, whereas total independence corresponds to 8 points. The ranking categories include $0-1$ : total dependency; 2-3: severe dependency; 4-5: moderate dependency; 6-7: slight dependency; and 8: independence. The inter-observer reliability for this questionnaire was 0.85 .

The Zarit Burden Inventory scale [30] was also used to identify the caregivers' overload. This is an instrument used to quantify the degree of overload suffered by caregivers of dependent adults. The Spanish version has 22 questions in a Likert format. For each item, the caregiver indicates how often they feel a certain way, using a scale of 1 (never), 2 (rarely), 3 (sometimes), 4 (quite a few times), and 5 (almost always). The scores obtained in each item were summarized, and the final score represented the overload degree of the caregiver. Its internal consistency was high, with a Cronbach alpha coefficient of 0.91 .

Lastly, the Duke-UNC-11 Functional Social Support Questionnaire [31] was used to determine the perceived social support of older caregivers. This scale has 11 items in a Likert response scale of 1 ("much less than I want") to 5 ("as much as I want"). The scoring ranges between 11 and 55 points. In the Spanish version, a cut-off point was chosen at the 15th percentile, corresponding to a score of $<32$. A score equal to or greater than 32 indicates standard support, while less than 32 points indicates perceived low social support. In the Spanish population, the internal consistency was 0.90 [32].

\subsection{Statistical Analysis}

In order to describe the total sample of caregivers, the prevalence of the categorical variables and the mean with standard deviation, the median, interquartile range (IR), and the maximum and minimum values (range) for the quantitative variables were calculated.

In light of the results of the Kolmogorov-Smirnov and Shapiro-Wilk tests, the data were analyzed with non-parametric methods. The Mann-Whitney U test or Chi-Square test was applied to evaluate between-gender differences. Furthermore, these tests were also used to compare those caregivers with a lack of strength with those who did not perceive they had a lack of strength. Hypothesis contrasts were considered significant when $p<0.05$.

The correlation coefficient of Spearman $\varrho$ (rho) was used to measure the association between variables. Hypothesis contrasts were considered significant when $p<0.05$. The statistical analysis was performed using SPSS version 22.0@ software for Windows.

\section{Results}

Table 1 shows the sociodemographic variables and characteristics of the total sample and both women and men caregivers. Statistically significant differences $(p<0.05)$ between genders were found for age, previous caregiving experience, doubts about better care, the gender of the person being cared for, and the ability to develop IADL.

Table 1. Sociodemographic variables and comparisons between women and men caregivers.

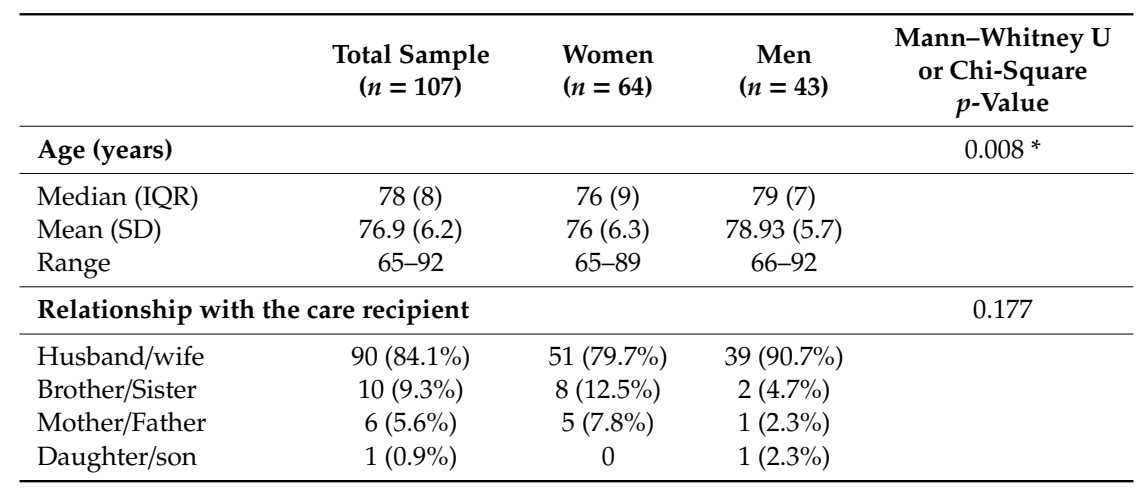


Table 1. Cont.

\begin{tabular}{|c|c|c|c|c|}
\hline & $\begin{array}{l}\text { Total Sample } \\
\quad(n=107)\end{array}$ & $\begin{array}{l}\text { Women } \\
(n=64)\end{array}$ & $\begin{array}{c}\text { Men } \\
(n=43)\end{array}$ & $\begin{array}{c}\text { Mann-Whitney U } \\
\text { or Chi-Square } \\
p \text {-Value }\end{array}$ \\
\hline \multicolumn{4}{|c|}{ Previous care experience $n(\%)$} & $<0.001 *$ \\
\hline Yes & $48(44.9 \%)$ & $45(70.3 \%)$ & $3(7 \%)$ & \\
\hline No & $59(55.1 \%)$ & $19(29.7 \%)$ & $40(93 \%)$ & \\
\hline \multicolumn{4}{|l|}{ Care years (years) } & 0.291 \\
\hline Median (IQR) & $4.5(7)$ & $4(7.75)$ & $5(7)$ & \\
\hline Mean (SD) & $5.92(4.59)$ & $5.84(5.16)$ & $6.03(3.63)$ & \\
\hline Range & $0.5-30$ & $0.5-30$ & $1-13$ & \\
\hline \multicolumn{4}{|l|}{ Care hours (hours) } & 0.733 \\
\hline Median (IQR) & $24(14)$ & $24(14)$ & $24(14)$ & \\
\hline Mean (SD) & $18.97(7.86)$ & $19.19(7.89)$ & $18.65(7.90)$ & \\
\hline Range & $2-24$ & $2-24$ & $3-24$ & \\
\hline \multicolumn{4}{|l|}{$\begin{array}{l}\text { Difficulty in care } n \\
(\%)\end{array}$} & 0.580 \\
\hline Yes & 77 (71.9\%) & $46(71.9 \%)$ & $31(72.1 \%)$ & \\
\hline No & $30(28.1 \%)$ & $18(28.1 \%)$ & $12(27.9 \%)$ & \\
\hline \multicolumn{4}{|c|}{ Lack of perceived physical strength $\mathbf{n}(\%)$} & 0.490 \\
\hline Yes & $76(71.0 \%)$ & 46 (71.9\%) & $30(69.8 \%)$ & \\
\hline No & $31(29.0 \%)$ & $18(28.1 \%)$ & $13(30.2 \%)$ & \\
\hline \multicolumn{4}{|c|}{ Present doubts about how to take better care $\mathbf{n}(\%)$} & $0.041 *$ \\
\hline Yes & $20(18.7 \%)$ & $8(12.5 \%)$ & $12(27.9 \%)$ & \\
\hline No & $87(81.3 \%)$ & $56(87.5 \%)$ & $31\left(72 .{ }^{\circ} \%\right)$ & \\
\hline \multicolumn{4}{|l|}{ Need help n (\%) } & 0.155 \\
\hline Yes & 75 (70.1\%) & $42(65.6 \%)$ & $33(76.7 \%)$ & \\
\hline No & $32(29.9 \%)$ & $22(34.4 \%)$ & $10(23.3 \%)$ & \\
\hline \multicolumn{4}{|c|}{ Perceived social support } & 0.460 \\
\hline Median (IQR) & $45(16)$ & 44.50 (16.75) & $48(17)$ & \\
\hline Mean (SD) & $42.41(12.21)$ & 41.69 (12.65) & 43.49 (11.60) & \\
\hline Range & $11-55$ & $11-55$ & 13-55 & \\
\hline \multicolumn{4}{|c|}{ Dependency degree of the care receiver $n(\%)$} & 0.078 \\
\hline $\begin{array}{l}\text { Moderate } \\
\text { dependence }\end{array}$ & $30(28.0 \%)$ & $23(35.9 \%)$ & $7(16.3 \%)$ & \\
\hline Severe dependence & $26(24.3 \%)$ & $13(20.3 \%)$ & $13(30.2 \%)$ & \\
\hline Total dependence & $51(47.7 \%)$ & $28(43.8 \%)$ & $23(53.5 \%)$ & \\
\hline \multicolumn{4}{|c|}{ Gender of the care receiver $n(\%)$} & $<0.001 *$ \\
\hline Women & $46(43.0 \%)$ & $9(14.1 \%)$ & $37(86.0 \%)$ & \\
\hline Men & $61(57.0 \%)$ & $55(85.9 \%)$ & $6(14.0 \%)$ & \\
\hline \multicolumn{4}{|l|}{ Barthel Index (ADL) } & 0.235 \\
\hline Median (IQR) & $95(15)$ & $95(10)$ & $95(10)$ & \\
\hline Mean (SD) & $90.65(10.64)$ & 90.55 (12.34) & $90.81(7.55)$ & \\
\hline Range & $45-100$ & $45-100$ & $65-100$ & \\
\hline \multicolumn{4}{|c|}{ Lawton and Brody (IADL) } & $0.006^{*}$ \\
\hline Median (IQR) & $6(3)$ & $6(3)$ & $5(4)$ & \\
\hline Mean (SD) & $5.39(2.22)$ & $5.86(2.11)$ & $4.70(2.22)$ & \\
\hline Range & $1-8$ & $1-8$ & $1-8$ & \\
\hline \multicolumn{4}{|l|}{ Perceived burden } & 0.416 \\
\hline Median (IQR) & $47(28)$ & $44.50(26.75)$ & $52(30)$ & \\
\hline Mean (SD) & 47.78 (15.53) & 46.59 (15.17) & $49.53(16.06)$ & \\
\hline Range & 26-84 & 26-84 & $27-83$ & \\
\hline
\end{tabular}

* $p$-value < 0.05; SD: Standard Deviation; IQR: Interquartile Range. Barthel: 0-20: total dependence; 21-60: severe dependence; 61-90: moderate dependence; 91-99: light dependence; 100: independent; Lawton and Brody: 0-1: total dependence; 2-3: severe dependence; 4-5: moderate dependence; 6-7: light dependence; 8: independence; Zarit: $\leq 46$ : do not perceive burden; $47-55$ : mild burden perception; $\geq 56-110$ : heavy burden perception; questionnaire DUKE-UNC: $\geq 32$ : regular support; $<32$ low social support perceived. 
Table 2 shows the differences between those participants who reported a perception of inadequate strength levels and those who perceived they did not have a lack of strength. Age was slightly different between groups, and those who were older showed a higher perceived lack of strength but did not reach the statistically significance level $(p=0.051)$.

Table 2. Differences between those who perceived they had a lack of strength and those who did not.

\begin{tabular}{|c|c|c|c|}
\hline & $\begin{array}{l}\text { Lack of Strength } \\
\qquad(n=76)\end{array}$ & $\begin{array}{l}\text { No Lack of Strength } \\
\qquad(n=31)\end{array}$ & $\begin{array}{l}\text { Mann-Whitney U or } \\
\text { Chi-Square } p \text {-Value }\end{array}$ \\
\hline Age (years) & & & 0.051 \\
\hline Median (IQR) & $79(9)$ & $76(8)$ & \\
\hline Mean (SD) & $77.61(6.44)$ & $75.16(5.50)$ & \\
\hline Range & $65-92$ & $65-85$ & \\
\hline Difficulty in care $n(\%)$ & & & $<0.001 *$ \\
\hline Yes & $71(93.4 \%)$ & $6(19.4 \%)$ & \\
\hline No & $5(6.6 \%)$ & $25(80.6 \%)$ & \\
\hline Need help n (\%) & & & $<0.001 *$ \\
\hline Yes & $62(81.6 \%)$ & $13(41.9 \%)$ & \\
\hline No & $14(18.4 \%)$ & $18(58.1 \%)$ & \\
\hline Perceived social suppor & & & 0.491 \\
\hline Median (IQR) & $45(16)$ & $49(22)$ & \\
\hline Mean (SD) & $42.82(10.75)$ & $41.42(15.39)$ & \\
\hline Range & $11-55$ & $12-55$ & \\
\hline \multicolumn{3}{|c|}{ Dependency degree of the care receiver $\mathbf{n}(\%)$} & 0.008 \\
\hline Moderate dependence & $15(19.7 \%)$ & $15(48.4 \%)$ & \\
\hline Severe dependence & $19(25 \%)$ & $7(22.6 \%)$ & \\
\hline Total dependence & $42(55.3 \%)$ & $9(29.0 \%)$ & \\
\hline \multicolumn{3}{|c|}{ Gender of the care receiver $n(\%)$} & 0.531 \\
\hline Women & $33(43.4 \%)$ & $13(41.9 \%)$ & \\
\hline Men & $43(56.6 \%)$ & $18(58.1 \%)$ & \\
\hline Barthel Index (ADL) & & & $<0.001 *$ \\
\hline Median (IQR) & $90(10)$ & $100(5)$ & \\
\hline Mean (SD) & $88.42(11.52)$ & $96.13(4.95)$ & \\
\hline Range & $45-100$ & $85-100$ & \\
\hline \multicolumn{3}{|c|}{ Lawton and Brody (IADL) } & $<0.001 *$ \\
\hline Median (IQR) & $5(4)$ & $7(2)$ & \\
\hline Mean (SD) & $4.88(2.29)$ & $6.65(1.43)$ & \\
\hline Range & $1-8$ & $3-8$ & \\
\hline
\end{tabular}

Clear between-group differences were observed in difficulty in care and need for help. In these categories, most caregivers with a lack of strength reported that they had difficulties (93.4\%) and needed help (81.6\%).

As shown in Table 3, a direct correlation existed between perceived lack of physical strength and the ability to perform basic and instrumental activities $(p<0.01)$, the need for caregiver assistance $(p<0.01)$, and the social support perceived $(p<0.05)$ An inverse correlation existed between the conception of the perceived lack of physical strength and the dependence degree of the care receiver $(p<0.01)$. 
Table 3. Relationship of the lack of physical strength perceived.

\begin{tabular}{lcccccc}
\hline & \multicolumn{5}{c}{ Lack of Physical Strength Perceived } \\
\cline { 2 - 7 } & \multicolumn{2}{c}{ Total Group } & \multicolumn{2}{c}{ Men } & \multicolumn{2}{c}{ Women } \\
\cline { 2 - 7 } & $\mathbf{r}$ & $p$ & $\mathbf{r}$ & $p$ & $\mathbf{r}$ & $p$ \\
\hline Barthel Index (ADL) & $0.382^{* *}$ & $<0.001$ & $0.410^{* *}$ & 0.006 & $0.373^{* *}$ & 0.002 \\
\hline Lawton and Brody (IADL) & $0.370^{* *}$ & $<0.001$ & $0.364^{*}$ & 0.016 & $0.437^{* *}$ & $<0.001$ \\
\hline Dependency degree of care receiver & $-0.288^{* *}$ & 0.003 & -0.163 & 0.297 & $-0.368^{* *}$ & 0.003 \\
\hline Need help & $0.393^{* *}$ & $<0.001$ & $0.477^{* *}$ & 0.001 & $0.352^{* *}$ & 0.004 \\
\hline Perceived social support & $-0.208^{*}$ & 0.031 & 0.035 & 0.825 & $-0.285^{*}$ & 0.022 \\
\hline Perceived burden & -0.184 & 0.058 & -0.280 & 0.069 & -0.125 & 0.324 \\
\hline r: Spearman correlation coefficient ${ }^{* *}$ correlation is significant at 0.01 level, $*$ correlation is significant at 0.05 level.
\end{tabular}

In the gender analysis, the Spearman correlation coefficient showed a direct relationship among perceived lack of physical strength in both women and men, the ability to perform basic and instrumental activities, and the need for help.

Women had an inverse correlation between the perceived physical strength and the dependency of their care-dependent person. However, this correlation was absent in men.

In the same way, the social support perceived by older women caregivers was inversely correlated with the perception of a lack of physical strength.

\section{Discussion}

The main finding of the present study was that $71 \%$ of the older caregivers from rural areas perceived a lack of physical strength. This proportion was similar among male and female older adults, which indicates that both men and women perceived that they have a lack of strength to carry out caregiving tasks. Comparing those with perceived lack of strength and those with enough strength, we can observe how caregivers from the first group need more help, have more difficulties, and show less ability to perform ADL. Furthermore, the dependence level of the person who receives care is also a relevant variable, since more than $80 \%$ of the people who had a perceived lack of strength are caring for people with severe or total dependence. Therefore, the perception of strength may be a crucial variable to successfully conduct caregiving.

Caregivers' health conditions deteriorate with age. As a consequence of normal aging, physical strength and interaction with the social environment decreases [33]. In this sense, our results confirm that the lack of physical strength may determine the need for help in older caregivers from rural areas. Although the prevalence of degenerative muscle mass loss and strength is often higher in older women than in older men [34], there were no differences between the proportion of men reporting lack of strength and the proportion of women with the same perception. Although hypothetical, since most studies reported this result, it is likely that these men measured strength more objectively than women do. They could even have a more absolute perception of strength [35], but when they were asked about the lack of strength to carry out caregiving tasks, these differences were highly reduced.

One of the consequences of sarcopenia [36], an overall loss in skeletal muscle mass that progresses with age, is the decline of gripping force. This fact would support our finding that older caregivers who perceive a lack of physical strength are those who take care of more dependent people and consequently need to develop more tasks and responsibilities where gripping force is crucial. In this regard, older people in primary caregiving roles who have decreased their ability to perform basic and instrumental activities also have a more significant loss of physical strength [33]. Our findings confirm the association between ADL, IADL, and a perceived lack of physical strength.

Due to the physical demands of the care process, caregivers have better scores than non-caregivers on body composition and strength (in both upper and lower limbs) [37]. Nevertheless, they tend to 
perceive this strength as insufficient to perform some care-related activities [37]. Therefore, strength training interventions in caregivers could increase the satisfaction of the older caregiver in care-related activities. Resistance exercise training can increase muscle mass and strength. Recent evidence suggests that muscle power is an important determinant of functional capacity. Moreover, nutritional interventions, such as the increase of creatine monohydrate, milk-based proteins, and essential fatty acids in the diet, all have biological effects that may potentiate the beneficial effects of exercise in older adults [18,38].

Apart from the physical function variables, cultural factors in the care process are relevant $[39,40]$, since they could condition the care situation perception and its consequences [41-43]. In this regard, older adults could see the care process as a moral obligation and may feel guilty if they do not perform the needed functions [44]. This could lead to situations where the caregivers perform tasks that might involve different kind of risks, such as injuries, muscle soreness, anxiety, and falls. Thus, the evaluation and improvement of physical fitness are essential in this population, since they are going to perform those tasks even when their own health is at risk. To do that, a simple test called the International Fitness Scale (IFIS), which has been validated in older adults, can be used to evaluate a person's perception of their own physical fitness [35]. Through this scale, the potential physical limitations of the caregivers may be identified, and tailored interventions can be conducted.

This study had some limitations. First, we did not use population-based sampling strategies, which limited its generalization as normative values for older caregivers in Spain. However, the socio-demographic characteristics of caregivers were consistent with those reported by large studies previously conducted in Spain $[45,46]$. Moreover, the physical strength assessment of older caregivers was not objectively assessed, and only the response of the individual's perception was used. Thus, an in-depth analysis of physical strength requires adding an objective measure of the variable, as well as other variables, such as the weight of the care recipient, the tasks performed, and the instruments or techniques used to mobilize them. In addition, through specific virtual training applications, the caregiver could perceive an increase in strength.

New information and communication technologies (ICTs) have become essential tools in the health sector and an option for caregiver support. Instruments and procedures have been defined that allow the acquisition, treatment, communication, and recording of information in the form of voice, images, and data contained in acoustic, optical, or electromagnetic signals [47]. In general, ICTs are an aid for caregivers who have limited free time, and the use of ICTs would solve the problem of travel, which often limits the caregiver $[37,48]$. The advantages of ICTs include: (1) the support of the exchange of information; (2) an improved access to medical care; (3) a reduction in costs; and (4) the ability to receive personalized medical care [49-51]. In line with our results, future works should study the use of tele-exercise and telemedicine as tools to support older caregivers. In this regard, a previous study showed that tele-medicine had positive effects on muscle strength in older adults [52]. This kind of intervention should be useful in older caregivers, who usually have limited free time. However, the ICT applications used in health services have some limitations among older adults because older adults frequently resist the use of new technologies [53]. In this regard, future studies should investigate the best tool or training method for the acquisition of new knowledge and skills necessary for the use of electronic devices and information systems.

Caregivers require technological tools that allow them to provide better care, and more timely and efficient care for the dependent patient. The applications and services that are currently being developed facilitate the improvement of quality, equality, and access to social and medical care [54].

\section{Conclusions}

In our study, more than $70 \%$ of the older caregivers from rural areas perceived they had a lack of strength to conduct their caregiving tasks. Caregivers with a perceived lack of strength need more help, have more difficulties physically caring for others, and show less ability to perform ADL than those without a lack of strength. Furthermore, more than $80 \%$ of the people who had a perceived 
lack of strength are caring for people with severe or total dependence. Therefore, the perception of strength and the characteristics of the cared person may be crucial variables to successfully conduct caregiving tasks.

Older caregivers who have a perception of low social support also perceive a lack of strength to perform care tasks. These findings imply the need to include the perceived physical strength in the comprehensive assessment of older caregivers, in order to identify caregiver's limitations and needs in their usual care-related activities.

Author Contributions: Conceptualization, L.M.-B.; Data curation, L.M.-B.; Formal analysis, S.V., D.C.-M. and J.C.A.; Funding acquisition, L.M.-B. and S.P.-M.; Investigation, J.C.A.; Methodology, L.M.-B. and S.V.; Resources, S.P.-M. and J.C.A.; Supervision, D.C.-M., S.P.-M. and J.C.A.; Validation, S.V.; Writing-original draft, L.M.-B., S.V. and D.C.-M.; Writing-review \& editing, S.V., D.C.-M. and S.P.-M.

Funding: The author S.V. was supported by a grant from the regional department of economy and infrastructure of the Government of Extremadura and the European Social Fund (PD16008).

Acknowledgments: In this section you can acknowledge any support given which is not covered by the author contribution or funding sections. This may include administrative and technical support, or donations in kind (e.g., materials used for experiments).

Conflicts of Interest: The authors declare no conflict of interest. The funders had no role in the design of the study; in the collection, analyses, or interpretation of data; in the writing of the manuscript, or in the decision to publish the results.

\section{References}

1. Fujisawa, R.; Colombo, F. The Long-Term Care Workforce: Overview and Strategies to Adapt Supply to a Growing Demand; OECD Publishing: Paris, France, 2009.

2. de Lima, R.A. Chronic conditions and the challenges for knowledge production in health. Rev. Lat. Am. Enferm. 2013, 21, 1011-1012. [CrossRef] [PubMed]

3. López Gil, M.; Orueta Sánchez, R.; Gómez-Caro, S.; Sánchez Oropesa, A.; Carmona de la Morena, J.; Moreno, A.; Javier, F. El rol de Cuidador de personas dependientes y sus repercusiones sobre su Calidad de Vida y su Salud. Rev. Clín. Med. Fam. 2009, 2, 332-339. [CrossRef]

4. Baster Moro, J.C. Adultos mayores en funciones de cuidadores de ancianos. Rev. Cuba. Salud Pública 2012, 38, 168-173. [CrossRef]

5. Francesca, C.; Ana, L.-N.; Jérôme, M.; Frits, T. OECD Health Policy Studies Help Wanted? Providing and Paying for Long-Term Care: Providing and Paying for Long-Term Care; OECD Publishing: Paris, France, 2011; Volume 2011.

6. IMSERSO. Encuesta de Apoyo Informal a los Mayores en España; Ministerio de Trabajo y Asuntos Sociales: Madrid, Spain, 2004.

7. Pinquart, M.; Sörensen, S. Differences between caregivers and noncaregivers in psychological health and physical health: A meta-analysis. Psychol. Aging 2003, 18, 250. [CrossRef] [PubMed]

8. Goren, A.; Montgomery, W.; Kahle-Wrobleski, K.; Nakamura, T.; Ueda, K. Impact of caring for persons with Alzheimer's disease or dementia on caregivers' health outcomes: Findings from a community based survey in Japan. BMC Geriatr. 2016, 16, 122. [CrossRef]

9. Guedes, A.; Pereira, M. Sobrecarga, enfrentamiento, síntomas físicos y morbilidad psicológica en cuidadores de familiares dependientes funcionales. Rev. Lat. Am. Enferm. 2013, 21, 1-6.

10. Carter, J.H.; Lyons, K.S.; Stewart, B.J.; Archbold, P.G.; Scobee, R. Does age make a difference in caregiver strain? Comparison of young versus older caregivers in early-stage Parkinson's disease. Mov. Disord. 2010, 25, 724-730. [CrossRef]

11. Pinquart, M.; Sörensen, S. Spouses, adult children, and children-in-law as caregivers of older adults: A meta-analytic comparison. Psychol. Aging 2011, 26, 1. [CrossRef]

12. Borg, C.; Hallberg, I.R. Life satisfaction among informal caregivers in comparison with non-caregivers. Scand. J. Caring Sci. 2006, 20, 427-438. [CrossRef]

13. Vitaliano, P.; Echeverria, D.; Shelkey, M.; Zhang, J.; Scanlan, J. A cognitive psychophysiological model to predict functional decline in chronically stressed older adults. J. Clin. Psychol. Med. Settings 2007, 14, 177-190. [CrossRef] 
14. Tomomitsu, M.R.S.V.; Perracini, M.R.; Neri, A.L. Influência de gênero, idade e renda sobre o bem-estar de idosos cuidadores e não cuidadores. Rev. Bras. Geriatr. Gerontol. 2013, 16, 663-680. [CrossRef]

15. Garlo, K.; O'Leary, J.R.; Van Ness, P.H.; Fried, T.R. Burden in caregivers of older adults with advanced illness. J. Am. Geriatr. Soc. 2010, 58, 2315-2322. [CrossRef] [PubMed]

16. Schulz, R.; Sherwood, P.R. Physical and mental health effects of family caregiving. Am. J. Nurs. 2008, 108, 23-27. [CrossRef] [PubMed]

17. Dahlrup, B.; Ekstrom, H.; Nordell, E.; Elmstahl, S. Coping as a caregiver: A question of strain and its consequences on life satisfaction and health-related quality of life. Arch. Gerontol. Geriatr. 2015, 61, 261-270. [CrossRef]

18. Rolland, Y.; Czerwinski, S.; Abellan Van Kan, G.; Morley, J.E.; Cesari, M.; Onder, G.; Woo, J.; Baumgartner, R.; Pillard, F.; Boirie, Y.; et al. Sarcopenia: Its assessment, etiology, pathogenesis, consequences and future perspectives. J. Nutr. Health Aging 2008, 12, 433-450. [CrossRef]

19. Marcos, M.M.; De la Cuesta Benjumea, C. La experiencia del cuidado de las mujeres cuidadoras con procesos crónicos de salud de familiares dependientes. Aten. Prim. 2016, 48, 77-84. [CrossRef]

20. Franzén-Dahlin, Å.; Larson, J.; Murray, V.; Wredling, R.; Billing, E. Predictors of psychological health in spouses of persons affected by stroke. J. Clin. Nurs. 2007, 16, 885-891. [CrossRef]

21. Papastavrou, E.; Kalokerinou, A.; Papacostas, S.S.; Tsangari, H.; Sourtzi, P. Caring for a relative with dementia: Family caregiver burden. J. Adv. Nurs. 2007, 58, 446-457. [CrossRef]

22. Richardson, T.J.; Lee, S.J.; Berg-Weger, M.; Grossberg, G.T. Caregiver health: Health of caregivers of Alzheimer's and other dementia patients. Curr. Psychiatry Rep. 2013, 15, 367. [CrossRef]

23. Jennings, L.A.; Reuben, D.B.; Evertson, L.C.; Serrano, K.S.; Ercoli, L.; Grill, J.; Chodosh, J.; Tan, Z.; Wenger, N.S. Unmet needs of caregivers of individuals referred to a dementia care program. J. Am. Geriatrics Soc. 2015, 63, 282-289. [CrossRef]

24. Esparza, C. Discapacidad y dependencia en España. Inf. Portal Mayores 2011, 108, 1-20.

25. Mahoney, F.I.; Barthel, D.W. Functional evaluation: The Barthel Index: A simple index of independence useful in scoring improvement in the rehabilitation of the chronically ill. Md. State Med. J. 1965, 14, 61-65. [PubMed]

26. Loewen, S.C.; Anderson, B.A. Reliability of the modified motor assessment scale and the Barthel index. Phys. Ther. 1988, 68, 1077-1081. [CrossRef] [PubMed]

27. Collin, C.; Wade, D.T.; Davies, S.; Horne, V. The Barthel ADL Index: A reliability study. Int. Disabil. Stud. 1988, 10, 61-63. [CrossRef]

28. Shah, S.; Vanclay, F.; Cooper, B. Improving the sensitivity of the Barthel Index for stroke rehabilitation. J. Clin. Epidemiol. 1989, 42, 703-709. [CrossRef]

29. Lawton, M.P.; Brody, E.M. Assessment of older people: Self-maintaining and instrumental activities of daily living. Gerontologist 1969, 9, 179-186. [CrossRef]

30. Zarit, S.H.; Reever, K.E.; Bach-Peterson, J. Relatives of the impaired elderly: Correlates of feelings of burden. Gerontologist 1980, 20, 649-655. [CrossRef]

31. Broadhead, W.E.; Gehlbach, S.H.; De Gruy, F.V.; Kaplan, B.H. The Duke-UNC Functional Social Support Questionnaire: Measurement of social support in family medicine patients. Med. Care 1988, 26, 709-723. [CrossRef]

32. Bellón, J.A.; Delgado, A.; De Dios Luna, J.; Lardelli, P. Validez y fiabilidad del cuestionario de apoyo social funcional Duke-UNC-11. Aten. Prim. 1996, 18, 153-163.

33. Hsiao, C.L.; Chiou, C.J. Primary caregivers of home nursing care recipients: Their caregiving experience and related factors. J. Nurs. Healthc. Res. 2011, 7, 127-139.

34. Salvà, A.; Serra-Rexach, J.A.; Artaza, I.; Formiga, F.; i Luque, X.R.; Cuesta, F.; López-Soto, A.; Masanés, F.; Ruiz, D.; Cruz-Jentoft, A.J. La prevalencia de sarcopenia en residencias de España: Comparación de los resultados del estudio multicéntrico ELLI con otras poblaciones. Rev. Esp. Geriatr. Gerontol. 2016, 51, 260-264. [CrossRef] [PubMed]

35. Merellano-Navarro, E.; Collado-Mateo, D.; Garcia-Rubio, J.; Gusi, N.; Olivares, P.R. Validity of the International Fitness Scale "IFIS" in older adults. Exp. Gerontol. 2017, 95, 77-81. [CrossRef] [PubMed]

36. Lauretani, F.; Russo, C.R.; Bandinelli, S.; Bartali, B.; Cavazzini, C.; Di Iorio, A.; Corsi, A.M.; Rantanen, T.; Guralnik, J.M.; Ferrucci, L. Age-associated changes in skeletal muscles and their effect on mobility: An operational diagnosis of sarcopenia. J. Appl. Physiol. 2003, 95, 1851-1860. [CrossRef] [PubMed] 
37. Gusi, N.; Prieto, J.; Madruga, M.; Garcia, J.M.; Gonzalez-Guerrero, J.L. Health-related quality of life and fitness of the caregiver of patient with dementia. Med. Sci. Sports Exerc. 2009, 41, 1182-1187. [CrossRef]

38. Forbes, S.C.; Little, J.P.; Candow, D.G. Exercise and nutritional interventions for improving aging muscle health. Endocrine 2012, 42, 29-38. [CrossRef]

39. Dilworth-Anderson, P.; Goodwin, P.Y.; Williams, S.W. Can culture help explain the physical health effects of caregiving over time among African American caregivers? J. Gerontol. Ser. B Psychol. Sci. Soc. Sci. 2004, 59, S138-S145. [CrossRef]

40. Knight, B.G.; Sayegh, P. Cultural values and caregiving: The updated sociocultural stress and coping model. J. Gerontol. Ser. B 2010, 65, 5-13. [CrossRef]

41. del-Pino-Casado, R.; Millán-Cobo, M.D.; Palomino-Moral, P.A.; Frías-Osuna, A. Cultural correlates of burden in primary caregivers of older relatives: A cross-sectional study. J. Nurs. Scholarsh. 2014, 46, 176-186. [CrossRef]

42. Lai, D.W.L. Filial piety, caregiving appraisal, and caregiving burden. Res. Aging 2010, 32, 200-223. [CrossRef]

43. Romero-Moreno, R.; Márquez-González, M.; Losada, A.; López, J. Motives for caring: Relationship to stress and coping dimensions. Int. Psychogeriatr. 2011, 23, 573-582. [CrossRef]

44. Lizarraga-Mansoa, S.; Ayarra-Elia, M.; Cabodevilla-Eraso, I. Atención a la familia del paciente al final de la vida. FMC Form. Méd. Cont. Aten. Prim. 2005, 12, 692-701. [CrossRef]

45. del Río Lozano, M.; del Mar García-Calvente, M.; Calle-Romero, J.; Machón-Sobrado, M.; Larrañaga-Padilla, I. Health-related quality of life in Spanish informal caregivers: Gender differences and support received. Qual. Life Res. 2017, 26, 3227-3238. [CrossRef] [PubMed]

46. del-Pino-Casado, R.; del Mar Pastor-Bravo, M.; Palomino-Moral, P.A.; Frías-Osuna, A. Gender differences in primary home caregivers of older relatives in a Mediterranean environment: A cross-sectional study. Arch. Gerontol. Geriatr. 2017, 69, 128-133. [CrossRef] [PubMed]

47. While, A.; Dewsbury, G. Nursing and information and communication technology (ICT): A discussion of trends and future directions. Int. J. Nurs. Stud. 2011, 48, 1302-1310. [CrossRef]

48. Fredman, L.; Bertrand, R.M.; Martire, L.M.; Hochberg, M.; Harris, E.L. Leisure-time exercise and overall physical activity in older women caregivers and non-caregivers from the Caregiver-SOF Study. Prev. Med. 2006, 43, 226-229. [CrossRef]

49. Organization, W.H. STRATEGY 2004-2007: eHealth for Health-Care Delivery; World Health Organization, Department of Essential Health Technologies: Geneva, Switzerland, 2004.

50. Ganesh, J. E-health drivers, applications, challenges ahead and Strategies: A conceptual framework. Indian J. Med. Inform. 2004, 1, 40-48.

51. DeNardis, L. ITU-T Technology Watch Report. eHealth Standards and Interoperability. April 2012. Available online: https://www.itu.int/dms_pub/itu-t/oth/23/01.T23010000170001PDFE.pdf (accessed on 2 October 2015).

52. Hong, J.; Kim, J.; Kim, S.W.; Kong, H.J. Effects of home-based tele-exercise on sarcopenia among communitydwelling elderly adults: Body composition and functional fitness. Exp. Gerontol. 2017, 87, 33-39. [CrossRef]

53. Dubois, B.; Feldman, H.H.; Jacova, C.; Cummings, J.L.; Dekosky, S.T.; Barberger-Gateau, P.; Delacourte, A.; Frisoni, G.; Fox, N.C.; Galasko, D.; et al. Revising the definition of Alzheimer's disease: A new lexicon. Lancet Neurol. 2010, 9, 1118-1127. [CrossRef]

54. Lauriks, S.; Reinersmann, A.; Van der Roest, H.G.; Meiland, F.J.; Davies, R.J.; Moelaert, F.; Mulvenna, M.D.; Nugent, C.D.; Droes, R.M. Review of ICT-based services for identified unmet needs in people with dementia. Ageing Res. Rev. 2007, 6, 223-246. [CrossRef]

(C) 2019 by the authors. Licensee MDPI, Basel, Switzerland. This article is an open access article distributed under the terms and conditions of the Creative Commons Attribution (CC BY) license (http://creativecommons.org/licenses/by/4.0/). 